\title{
Skill Development in Science and Technology Education for Sustainable Development in Nigeria
}

\author{
M. N. Modebelu (Corresponding author) \\ College of Agricultural and Science Education \\ Michael Okpara University of Agriculture, Umudike \\ Abia State of Nigeria \\ E-mail: meloodyne@gmail.com \\ S. A. Ugwuanyi \\ College of Agricultural and Science Education \\ Michael Okpara University of Agriculture, Umudike \\ E-mail: Abia State of Nigeria
}

\begin{abstract}
This paper reviews skill development in science and technology education, which is of crucial importance for sustainable development in Nigeria. The relevant concepts are introduced and robust argumentation is made with respect to the context of Nigeria.
\end{abstract}

Keywords: skill development, education, Nigeria

\section{Introduction}

The objective of skill development is not only timely, but appropriate in view of the present global socio-economic challenges. In Nigeria, the issue of skill development is particularly topical considering the structural, academic, vocational and planning challenges which are peculiar to Nigerians. Human capital development and wealth creation are important components of the 7-point Agenda of Nigeria previous administration, targeted to develop the national economy for sustainable development hence, making Nigeria one of the 20 largest economies by the year 2020. For Nigeria to move out of the present economic doldrums, its abundant human resources need to be developed and effectively and efficiently deployed to manage other natural resources, so as to attain to a high extent, the anticipated millennium development goals. One key factor militating against effective full utilization of the employment opportunities in the various sectors of the economy is lack of relevant skills. It is however true that no nation experiences development above the skill level of its human resources. Thus, the shortage of appropriately skilled labour across many industries is emerging as a significant and complex challenge to Nigerian economic growth and future development. Skills in all ramifications translate into inventions, services, products, ideas, innovations and best practices that drive the wheel of progress and development. To a very large extent, this depends on the caliber, organization and motivation of its human resources specifically, in Nigeria where cultural diversity exerts tremendous influence on politics and administration. The capacity to increase the benefits and reduce costs of this diversity constitutes a human resource management challenge of epic proportions. Particularly in our knowledge-based society, knowledge, skills, and resourcefulness of people are critical to sustaining economic and social development activities. Given the growing ICT networking and the dynamic investment climate in Nigeria, the demand for knowledge workers with high levels of technical and ICT skills can only increase. ICT knowledge and networking skills constitute the arrowhead of modern world of work, especially as most aspect of work is now computerized. Thus, it is only those who move with the tide in skills development will be successful.

\section{Concept of Skill}

Ogbuanya and Usoro (2010) defined skill as an expertise or ability developed in the course of training and experience. It includes not only trade and craft skills acquired by apprenticeship but also, high-grade performances in many fields, such as professional practice, the arts, games, and athletics. The three major components of skill are:

- Perception of subject/ events i.e. (art of perceiving all relevant factors).

- Choice of response (making a decision).

- Execution of the choice made (motor coordination and timing). In fact skill cannot be explained in word, but can only be demonstrated. Thus, the only way to learn a skill is through apprenticeship, training and experience. 
There are however, five major types of skills that individuals must acquire to be able utilize and apply science and technology to attain sustainable development. These are:

- Basic Skills: These include proficiency in reading, writing, simple calculations, communication and human relations.

- Technical Skills: These are capabilities in manipulating engines, machines, equipment, construction, computers etc,

- Professional Skills: These are required skills in fields like law, medicine, marketing, teaching, mining, surveying, architecture etc.

- Management/Leadership Skills: These cover areas like supervision, team-building, goal-setting, planning, motivation, decision-making, delegation, ethical-judgement etc.

- Intelligence Skills: These are innate capabilities. These manifest as self-awareness, self-discipline, persistence, sympathy, perseverance, intuition etc.

\section{Science and Technology Education}

Science and Technology Education are together the two major patent sources for social and economic changes in the contemporary history of mankind. Both disciplines have contributed immensely to make life worthwhile, whether in urban or rural areas, developed or developing countries. They have helped to promote health over disease, food surplus over famine, affluence over poverty, reason over superstition, education over ignorance. Yet, some of the world's worst problems have either been caused or promoted by science and technology education.

It seems difficult to separate science from technology education. However, one could see basic or pure science as a body of knowledge which has been systematically assembled and put together, in some sort of organized manner (Ajewole \& Owolabi, 2009). On the other hand, technology is simply an applied science which falls into so many areas of engineering, business, medicine, communication, agriculture, defense and so on (Musa, 2008). It should be noted that though, science and technology education are closely related and few people rarely make a distinction between them, yet two of them are not the same thing. While science is concerned with the search for knowledge and understanding about nature, technology deals with the application of the knowledge in the practical solution of problems of everyday life. The promotion and development of science and technology have come to stay in modern life. The importance is buttressed by human ability to tap materials and forces in nature in order to transform them into finished goods and services for vintage use. In recent times, science and technology have become powerful tools for resolving societal problems worldwide. Additionally, one of the proper ways the individual searches for truth and achieves understanding of the environment and the universe at large is the science and by extension technology. Indeed, many developed countries are lording it over the developing countries today on the basis of the exploits in the area of science and technology.

\section{Vocational-Technical Education as Skill Development Strategy}

We can therefore appreciate that skill development in any nation is critical to the economic survival and vibrancy of the individual, the community and the nation. This holds particularly true for developing nations like Nigeria that is still grappling with the chronic developmental factors as reflected in the Millennium Development Goals (MDGs). Vocational-Technical Education is multifaceted, multi-disciplinary and pragmatic field of study. It aims at equipping the individuals with requisite vocational-technical education skills which will enhance their relevance and functionality in the society. As a result, it plays a vital and indispensable role in the development of the society. Vocational-Technical Education (VTE) is indeed any form of education whose purpose is to prepare person(s) for employment in an occupation or a group of occupations. As a matter of fact, VTE aims at developing not only practical skills, but also a whole range of other skills - like desirable work attitude and habits that make the recipient a very creative and resourceful individual (Federal Republic of Nigeria-FRN, 2004a). VTE is central in the acquisition of skills and techniques in a chosen occupation or profession to enable the individual earn a living. It is also training or re-training programmes given in schools or private classes under public supervision or control. Indeed that system of education which is predicated upon the teaching of skills, demands the professional or expert use of hands (Oranu, 2010). It provides for the continuous process of adaptation of the workers' training toward acquiring the minimum knowledge required for any changing circumstance and hence, it is result-oriented (Eze, 2008). It brings about technological advancement and aims to fit new manpower for employment and provides continuous training for those already qualified, so that they can keep abreast of modern working methods. By and large, whether in the formal school system, or through the open apprenticeship system or even the supervised industrial work experience (SIWES), the VTE is a major strategy for skill development.

\section{MDGs Veritable Tool for Attainment of Sustainable Development}

In order to address the problem of poverty and promote sustainable development, the United Nations Millennium Declaration was adopted in September 2000, at the largest gathering of heads of states committing countries, both rich and poor to do all they could to eradicate poverty, promote human dignity and equality, and achieve peace and democracy. The goals include those dedicated to eradicating extreme poverty and hunger, achieving universal primary education, promoting gender equality and empowering women, reducing child mortality, improving maternal health, combating HIV/AIDS, malaria and other diseases, ensuring environmental sustainability and developing a global partnership for development.

The eight main targets, using 1990 as the baseline are to: 
1. Eradicate extreme poverty and hunger. 2015 target is to halve proportion of people living on less than $\$ 1$ a day, and those suffering from hunger.

2. Achieve universal primary completion

3. Promote gender equality by 2005 , and achieve equity at all levels by 2015

4. Reduce child and maternal mortality i.e. to reduce by two thirds the child mortality rate;

5. Improve maternal health by 2015 target and reduce by three quarters the proportion of women dying in childbirth;

6. Combat AIDS, malaria and other diseases 2015 target Halt and begin to reverse the incidence of HIV-AIDS, malaria and other major diseases;

7. Ensure environmental sustainability and integrate the principles of sustainable development into country. Implement policies and programmes to reverse the loss of environmental resources. 2015 target is meant to reduce by half the proportion of people without access to clean drinking water and basic sanitation. By 2020, achieve a significant improvement in the lives of at least 100 million slum dwellers.

8. Develop a global partnership for development.

These are no measurable, but goal 8 commits north and south to working together to achieve an open, rule-based trading and financial system, more generous aid to countries committed to poverty reduction, and relief for the debt problems of developing countries. It draws attention to the problems of the least developed countries and of landlocked countries and small-island developing states, which have greater difficulty competing in the global economy.

It is important to point out that there are limitations of utilizing the MDGs as a framework for delivering or measuring development. First, they risk simplifying what development is all about, by restricting the goals to what is measurable. Many aspects of development cannot be easily measured. Secondly, some of the goals are very modest e.g. the goal to half the pre-portion of people living on less than 1 \$ a day by 2015 and the target to achieve a significant improvement in the lives of at least 100 million slum dwellers by 2020 . Finally, some of the targets do not address the problems holistically. For instance, the MDG on education talks only of a full course of primary schooling with no reference to secondary and tertiary education.

Despite the limitations mentioned above, it is necessary, for us to engage the MDGs for many reasons. First, the MDGs draw together in a single agenda, issues that require priority to address the development question. Secondly, the MDGs have received tremendous endorsement and backing by world's governments. Thirdly, the MDGs have the advantage of being more or less measurable, few in number, concentrated on human development and focused almost on a single date -2015 .

Another advantage of the MDGs is that it adds urgency and transparency to international development. Finally, explicit resource commitment has been made to achieve the MDGs.

\section{MDGs Situation in Nigeria}

The situation of MDGs in Nigeria can be seen from two main sources; the Nigeria MDGs reports 2004 and the Nigeria MDGs reports 2005. The 2004 report which was Nigeria's first report on the MDGs states that "based on available information it is unlikely that the country will be able to meet most of the goals by 2015 , especially the goals related to eradicating extreme poverty and hunger, reducing child and maternal mortality and combating HIV/AIDS, malaria and other diseases". It further states that "for most of the other goals apart from goal 1, up-to-date data exists which shows that if the current trend continues, it will be difficult for the country to achieve the MDGs targets by 2015".

The Nigeria Millennium Development Goals 2005 report was the second in the series of annual reports on the MDGs in Nigeria. The report, which addressed the eight MDGs, highlights the current status and trends of each of the MDGs, the challenges and opportunities in attaining the goals, the promising initiatives that are creating a supportive environment and priorities for development assistance. The report concluded that:

There is high potential to attain some of the Millennium Development Goals which targets

- Achieving universal primary education.

- Ensuring environmental sustainability.

- Developing a global partnership for development.

Given the current policy environment and strong political will, there is also the likelihood of eradicating extreme poverty and hunger.

However, based on available information, there is the need for sustained efforts to ensure that the country meets the following goals by the year 2015:

- Achieving gender equality and women empowerment

- Reducing child mortality

- Improving maternal health; and

- Combating HIV/AIDS, malaria and other diseases. 
MDGs reports of 2005 appeared very opmistic and full of hope for not only Nigerians but to other third world nations. It has good indications and high potentials to achieving at least three of the goals, with particular reference to goals two, seven and eight. Achievement simply requires strong political will and sustained efforts which will in turn ensure that the nation meets the remaining goals. Attainment of the MDGs is a good indication and hope for bringing sustainable development into the nation. Development skills for sustainable development lie greatly on the nation's ability to develop citizens capable of utilizing science and technology to stimulate and steer competiveness in the modern labour market and also evoke knowledge-based as well as science/technology-based economy.

There actually exist an interface between skill development, science and technology for sustainable development in any nation. This paper has noted that skill development is essential for the promotion of socio-economic growth. It also observes the vital role usually played by the promotion of science and technology in enhancing the well-being of individuals in society. Indeed science discovers, but technology forms which produces goods and services using the appropriate skills and techniques. Developing skills in science and technology education to meet the demands of the sustainable development. Suffice it therefore for academics, to focus on the best strategies for skill development and effective utilization for the dream Nigeria qualitative sustainable development.

\section{Conclusion}

To achieve this kind of goals, therefore, our educational system needs be revisited. Particularly what we teach the students needs be re-examined in favour of vocational-technical education and entrepreneurship. We need to inject into the school curricula, those concepts and practices that should encourage vocational-technical education and entrepreneurship, which are capable of ensuring that individuals acquire employable skills. This will reduce unemployment and hence, poverty. It must be noted that poverty, is the key factor in the MDGs. When this has been reduced, other developmental factors will naturally decline.

When we emphasize the acquisition of skills in the educational system, the individuals whose skills have become obsolete will appreciate the need for retraining, while some others will now train for new and emerging jobs.

\section{Recommendation}

Both the federal government and the university management should ensure good environment for qualitative teaching, researching, community services as well effective students learning of science and technology in Nigerian tertiary institutions with particular reference to universities.

Academics should be adequately empowered to ensure quality facilitation science and technology education learning.

Academics should imbibe the skill of self-development and interest in science and technology by ensuring regular updating of skills in these areas for effective globalization and participation in the modern labour market.

Students should be enabled to acquire adequate science/technology skills for self-reliance and easy marketing of the saleable skills so acquire for employability at local and international levels.

Universities should be adequately equipped to discharge the expected roles as stipulated in Nigerian National Policy on Education.

\section{References}

Ajewole, G. \& Owolabi, T. (2009), A Handbook on Science Education for Tertiary Students. Lagos: Baba Olatunji Enterprises.

Eze, T.I. (2009), Policy Constraints to growth of technology education programs: implications for technology development in Nigeria. Proceedings of the International Conference on Recent Research and Development in Vocational-Technical Education II. National Centre for Research and Development Adelaide, Southwest Australia. 3(4), 205-212.

Federal Republic of Nigeria-FRN (2004a), National Policy on Education. Abuja: Nigeria Educational Research Council.

Federal Republic of Nigeria (2004b). Nigeria Millennium Development Report 2005. Abuja: National Planning Commission.

Kayode, A, (2009). Bridging the Skill Gap- in Nigeria: Framework for Dialogue between Universities and Employers of Labour. Ilorin: University of llorin.

Musa, A D. (2008). Technology and science education in Nigeria. Education Today, 6(3). 6-8.

Oranu, H.N. (2010), Vocational Education and Development. Nsukka: Nigeria Vocational Monograph Series.

UNDP (2003), Human Development Report Millennium Development Goals: A Compact Among Nations to End Human Poverty. New York: Oxford University Press.

Uwaifo, V.O. (2009), Industrializing the Nigerian Society through Creative Skill Acquisition of Vocational-Technical Education. International NGO, Journal, 4 (4). P. 142-145. 